\title{
A SWOT ANALYSIS OF ONLINE ROOM RESERVATION IN HOTEL SECTORS. (A CASE STUDY IN BALI HSOVEREIGN HOTEL)
}

\author{
I Wayan Kiki Sanjaya, A.A. Ayu Suwi Arianty, I Gusti Ayu Eka Suwintari, I Gusti \\ Ayu Melistyari Dewi \\ Institute of Tourism and Bisnis Internasional \\ kikisanjayabali@gmail.com
}

\begin{abstract}
The present study discusses a SWOT analysis of online reservation applied in HSovereign Hotel, Tuban, Bali. The hotel expects to obtain the easier and faster services in room reservation in hotel sectors by using internet media through online process (ecommerce). However, there are several challenges occur in practice as seen in HSovereign Hotel. As a result, the quality of thereservationservices is considered bad, not professional, and ultimately gives impact upon consumers' satisfaction. Therefore, the problem that will be observed in the present study is how the advantages, disadvantages, opportunities and threats of e-commerce usage in HSovereign Hotel can be identified. A descriptivequalitative research is the type of the present study. The data of the present studywere obtained from observation, interview, and documentation in order to find out the advantages, disadvantages, opportunities and threats of online reservation in $H$ Sovereign Hotel. Furthermore, the theories used in the present study are: hotel, reservation, room online reservation, definition of e-commerce, and room occupancy rate. The data were presented in both analytical descriptive and narrative, and also supported by presenting tables, maps, and figures. Based on the result of analysis, the advantages of e-commerce usage in online reservation services which attracted more residents to come is the effectiveness of online reservation system in $H$ Sovereign Hotel. On contrary, the disadvantages of online reservation relies on its dependency oninternet connection and server system in H Sovereign Hotel. The opportunity can be identified from using online reservation is it could be a media promotion which enables consumers to reserve in the last minute, and the threats found are cancellations ensue and fake bookings that extremely threaten information system of room reservation in H Sovereign Hotel.
\end{abstract}

Keywords: e-commerce; online reservation; SWOT analysis; H Sovereign Hotel.

\section{INTRODUCTION}

The growth of internet as an online system, especially the existence of ecommerce in hotel sectors has becomethe initiation of the present study. The internet usage in Indonesia, particularly in Bali, can give great opportunities for business, especially in hotel sectors. This belief is supported by a quotation from one of online newspapers, it stated that the population of internet users or also known as netter in Indonesia has reached 132,7 million people in 2016 (Bohang, 2018). For that reason, internet could be one of a media promotion in hotel sector. According to Vermaat (2007: 83), e-commerce, which stands for electronic 
commerce, is a business transaction that occurs in electronic system like internet does. Lately, the consumers are fond of e-commerce because of their several advantages, such as people are easy to observe the information of products, purchasing products, and the payment process of product is easy to do (Sihandrini, 2004: 3).

Nowadays, applying e-commerce in hotel sectors give positive impacts and it is an effective way in increasing the roomoccupancy rate. However, applying ecommerce in practice also has some disadvantages that eventually become certain challenge in achieving good service especially in reservation. This phenomenon occurs in H Sovereign Hotel which located in Tuban, Bali. The supporting fact has found from guest's complaint who stayed (Tripadvisor.com, 2016). The guest revealed her/his disappointment toward the hotel's reservation service that the guest has booked a room before but it was not shown in arrival list (accessed in October $21,2017)$. This phenomenon gives information that online reservation also has the disadvantages that derived from two factors, system error and human error. As a result, the overbooking in online reservation system ensues as seen in H Sovereign Hotel.

Considering all of the above matters, there is a point which become the urgency of the present study. The assumption that online reservation has a role to give advantages cannot be proven since $\mathrm{H}$ Sovereign Hotel is still taking great pain in arranging strategy in optimizing the role of that online reservation. Moreover, $\mathrm{H}$ Sovereign Hotel is a four-star hotel who shows its impressionthrough e-commerce. So the urgencies of this research will be the attempts to analyze the advantages, disadvantages, opportunities and threats of online reservation system by taking a case study in HSovereign Hotel that never been done before in this hotel.

\section{METHODOLOGY}

The present study used descriptive-qualitative research. In order to obtain the valid data, observations, interviews, and documentation studies were carried out. Afterward, to answer the research problems exist in the present study, the data were analyzed in SWOT matrix to compare the internal factors; advantages and disadvantages and the external factors; opportunities and threats. Furthermore, two theories were used in analyzing the data. The first theory was online reservation theory that presented the procedures and steps of online reservation in hotel sector. The second one was the consumer satisfaction theory that explains the expectation for service quality and the reality. Both theories were used since they are very relevant to analyze the condition of $\mathrm{H}$ Sovereign Hotel and to answer the research problems.

\section{RESULT AND DISCUSSION}

The investigation of documentation studies to recognize the history of $\mathrm{H}$ Sovereign Hotel has found some information. The hotel is operated under PT Karya Cipta Putera Pratama which actually has two brands hotel, another one is H Clarity Hotel located in Cihampelas, Bandung, West Java. Nevertheless, for certain conditions and considerations, that brand has sold in the middle of 2015 and its name was changed into Hotel Grand Tjokro Bandung. Therefore, H Sovereign Bali has been the only one brand that PT Karya Cipta Putera Pratama possesses until today. 
After almost five years of its existence, the hotel has given its contribution and has good reputation in providing accommodation for tourists who stay in Bali. Table 1 presents data related to market segment ofH Sovereign Hotel, room revenue, and the average room rates as follows :

Table 1

Market Segment Summary of H Sovereign Hotel in 2016

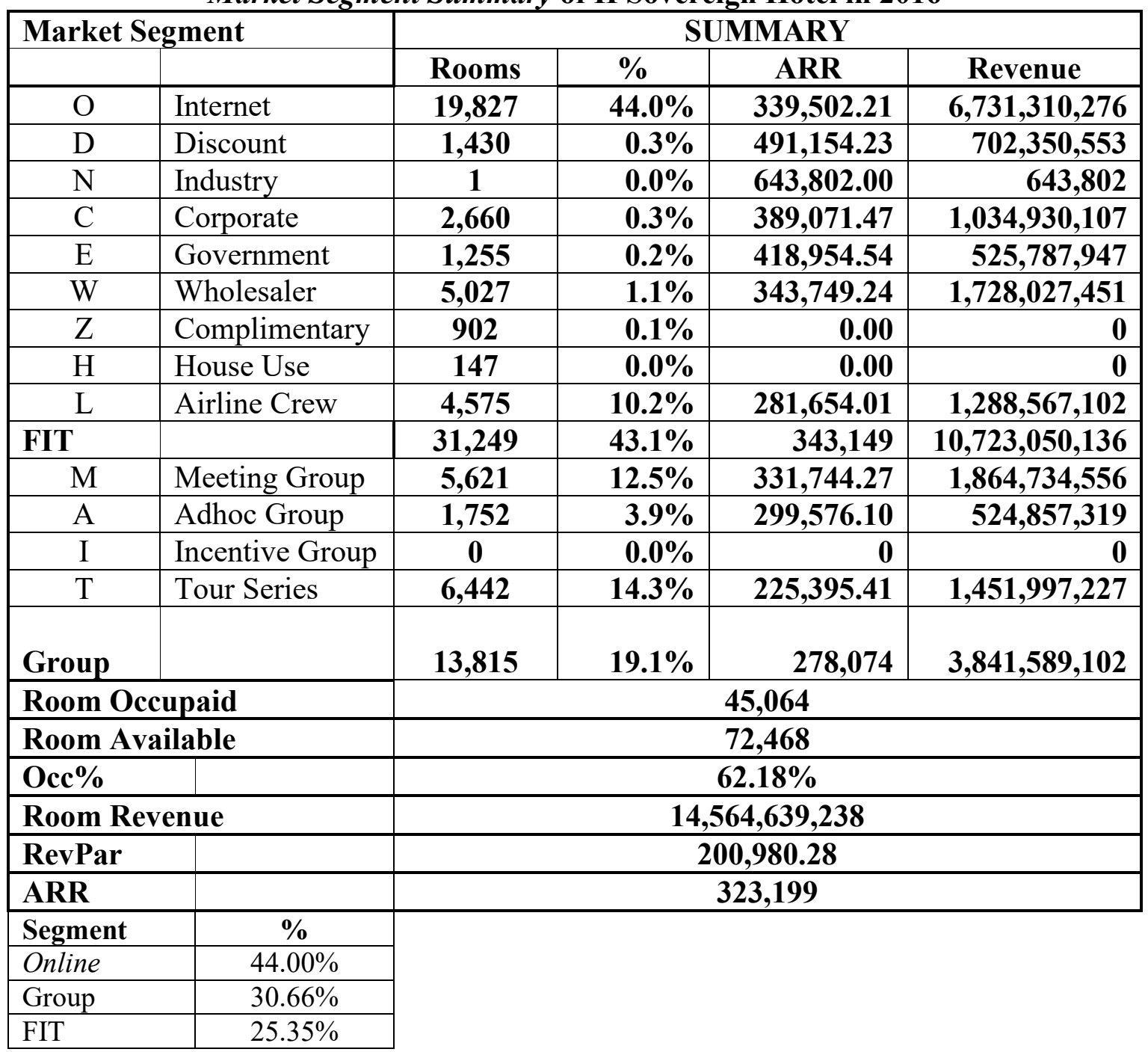

Source: Market Segmentation Summary H Sovereign (2017), processeddata.

By concerning the data presented in Table 1, the contribution of internet segment for online reservation in H Sovereign Hotel gains higher percentage upon room revenue, $44 \%$ for room revenue as much as 19.827 in 2016 . Because of online reservation is simple in process, many consumers are fond of doing reservation in online. Beside that, massive promotion which undertaken by online travel agent or person in creating hotel website and advertising through social media, such as Facebook, Google AdWords, Instagram, and YouTube may become the other factors. The condition of $\mathrm{H}$ Sovereign Hotel gives indication that the hotel profit derives from online reservation, particularly in promoting and completing room occupancy. Thus, it is also relevant with a concept proposed by Sugiarto (2002: 55), 
he reveals that the hotel management should do everything in order to increase its room occupancy, including do the online reservation as the strategy.

\section{A SWOT Analysis of Online Reservation in H Sovereign Hotel}

For the explanation of SWOT analysis in H Sovereign Hotel, the collected data will be analyzed in matrix as presented in Table 2:

\section{Table 2}

\section{Matrix SWOT of Online Reservation in HSovereign Hotel}

\begin{tabular}{|c|c|c|}
\hline EFAS & $\begin{array}{l}\text { Advantages } \\
\text { a. The effectiveness of } \\
\text { employing } \\
\text { reservation system in } \\
\text { online. } \\
\text { b. Online reservation is } \\
\text { superior in } \\
\text { accomplishing the } \\
\text { highest room } \\
\text { occupancy. }\end{array}$ & $\begin{array}{l}\text { disadvantages } \\
\text { 1. Online reservation has } \\
\text { dependence on internet } \\
\text { connection. } \\
\text { 2. The complexity in using } \\
\text { extranet. }\end{array}$ \\
\hline $\begin{array}{l}\quad \text { Opportunity } \\
\text { 1. Online reservation as } \\
\text { media promotion } \\
\text { 2. The existence of online } \\
\text { reservation enables } \\
\text { customers to do last- } \\
\text { minute reservation. }\end{array}$ & $\begin{array}{l}\text { SO Strategy } \\
\text { 1. Enlarge the cooperation } \\
\text { with other OTA. } \\
\text { 2. Increase promotion } \\
\text { activities. }\end{array}$ & $\begin{array}{l}\quad \text { WO Strategy } \\
\text { 1. Increase the quality of } \\
\text { internet. } \\
\text { 2. Give a training for } \\
\text { reservation staff who do } \\
\text { not comprehend yet the } \\
\text { usage of extranet. }\end{array}$ \\
\hline $\begin{array}{l}\quad \text { Threat } \\
\text { 1. The occurrence } \\
\text { ofcancellation, no show, } \\
\text { and fake booking is } \\
\text { regarded as threats } \\
\text { affecting a financial } \\
\text { loss. }\end{array}$ & \begin{tabular}{l}
\multicolumn{1}{c}{ ST Strategy } \\
1. Ask the guests to make \\
deposit to guarantee the \\
room occupancy. \\
2. Analyze the market \\
segments who suspected \\
do fake booking \\
frequently.
\end{tabular} & $\begin{array}{l}\text { WT Strategy } \\
\text { 1. Apply direct booking(walk } \\
\text { in) and ask for half } \\
\text { payment in advance } \\
\text { (cash). } \\
\text { 2. Keep a good cooperation } \\
\text { with offline travel agent. }\end{array}$ \\
\hline
\end{tabular}

Source: primer data has been processed

There are opportunities and threats occur as the impacts of applying online reservation in $\mathrm{H}$ Sovereign Hotel despite of its advantages and disadvantages. The following discussion will present complete explanation for each analysis:

\section{Advantages}

By comparing the common conventional reservation with online reservation, it is clear that online reservation is more effective. The easy access for information and 
the efficiency of time could be the reason behind. In interview with a revenue manager of $\mathrm{H}$ Sovereign Hotel, Andi Astika, gave information as follows :

"We do not need a long time to get the information of guests as our system will work by itself to process the data so that the information of the guest obtained. On the other hand, applying conventional reservation, such as telephone or walk-in reservation (a reservation by visiting the hotel), needs more time to obtain the data of the reservation since the staff of reservation have to communicate verbally. So, that is the strength of online reservation if we take a look on its process that is more efficient than manual reservation. Moreover, online reservation can be done everywhere as long as you have internet connection" (interview, June 3, 2017)

By looking deeply in online reservation side, the theories of practitioner, Astika and Bagyono (2008: 251) about the function of hotel reservation are quite relevant. Both of them are tendentious and strengthen the vital function of reservation to build a good image of hotel service. In other words, the role of online reservation is not only to hasten the service but also to cut the reservation process itself so that it will take a short time. Meanwhile, this situation build the opinion or image of clients upon the good service of $\mathrm{H}$ Sovereign Hotel. Then, another interesting point is the fact that the process of online reservation is more efficient than the conventional one. Table 1 has shown that the online reservation has the highest percentage, $44 \%$. This fact also answers the advantages of online reservation than conventional reservation.

\section{Disadvantages}

Despite of its advantages, the online reservation apparently has two disadvantages. First, online reservation highly depends on internet. Second, the complexity of extranet usage makes the staff difficult to do adaptation with the system used. The data entails the disadvantages of online reservation is obtained from Astika in following quotation:

"....the network of internet server is frequently get troubles like some error or slow connection exists when there is a meeting group or sort of event that also needs internet network. Internet quota is more needed to sustain the process of meeting group that occurs. It is due to giving a good service for the guest is a priority. Because the online reservation is highly depends on internet connection, it will distract the reservation activities in hotel. It happens since online reservation can be accessed if there is internet network...” (interview, June 3, 2017)

By analyzing more the results of interview, it can be assumed that error connection in internet may cause the application of online reservation cannot receive any reservation properly. As a result, the reservation system of room booking from the guests cannot be listed in H Sovereign Hotel's system.

For the next point, the complexity of extranet usage is simultaneously become the disadvantages of $\mathrm{H}$ Sovereign Hotel. This information obtained from Andi Astika as shown in following quotation : 
"...the complexity of extranet usage is experienced by our reservation staff when they update the information related to room availability, room rate, pictures, and also when promote something in hotel website or OTA....We often call OTA to give training to our staff- our reservation staff who do not know well the operation system of the extranet..." (interview, June 3, 2017).

The problem on the complexity of extranet in H Sovereign Hotel does make sense. If it is continuously happened, it will affect the productivity of reservation staff. While the complexity of extranet does not handled by a competent staff, it will be an influential factor to set up wrong price or promotion that eventually inflict a financial loss. Other problems that makes difficult to sustain extranet and online reservation are a policy that hotel must give commission for every reservation through OTA, updating the price, and set up room occupancy to agent. These two points are frequently affect the guest's complaint as seen in background.

If these points are related to the consumer's satisfaction theory, it turns out that the speed service that does not satisfy the clients could be the threat for hotel. Engel et. al (in Tjiptono, 2002: 146) reveals that consumer's satisfaction is a finished purchasing evaluation that the alternative chosen at least will give the same outcome or out of consumers expectation. The phenomenon in H Sovereign Hotel which is irrelevant with theory of consumer's satisfaction is shown when the speed of online service and the extranet system handled by hotel is failed to fulfill the guest's satisfaction that ultimately emerges many complaints.

\section{Opportunities}

Talking about the opportunities of online reservation in H Sovereign Hotel , two points are found. First, the existence of online reservation could be media promotion and gaining impression for hotel. Second, the opportunity to fill the room occupancy to have last-minute reservation. These two points are the result of an interview with AndiAstika.

First, having said about the opportunity that online reservation can build good impression has been considered by $\mathrm{H}$ Sovereign Hotel. It is proven by the hotel are willing to pay promotion fee through media in certain website to advertise in various search engines, one of them is owned by Google Inc. To enhance this assumption, the representative of online marketing agent from booking.com, Mrs.Elie, gave some comments as shown in following quotation :

"...yap, that is true that we has promoted many hotels, including $\mathrm{H}$ Sovereign Hotel in order to have a good cooperation in advertisements in search engine like Google.com through Google AdWords. It is carried out to introduce hotels in different market segments besides they can get a large amount of online reservation from our website (booking.com)..." (interview, September 8, 2017) 


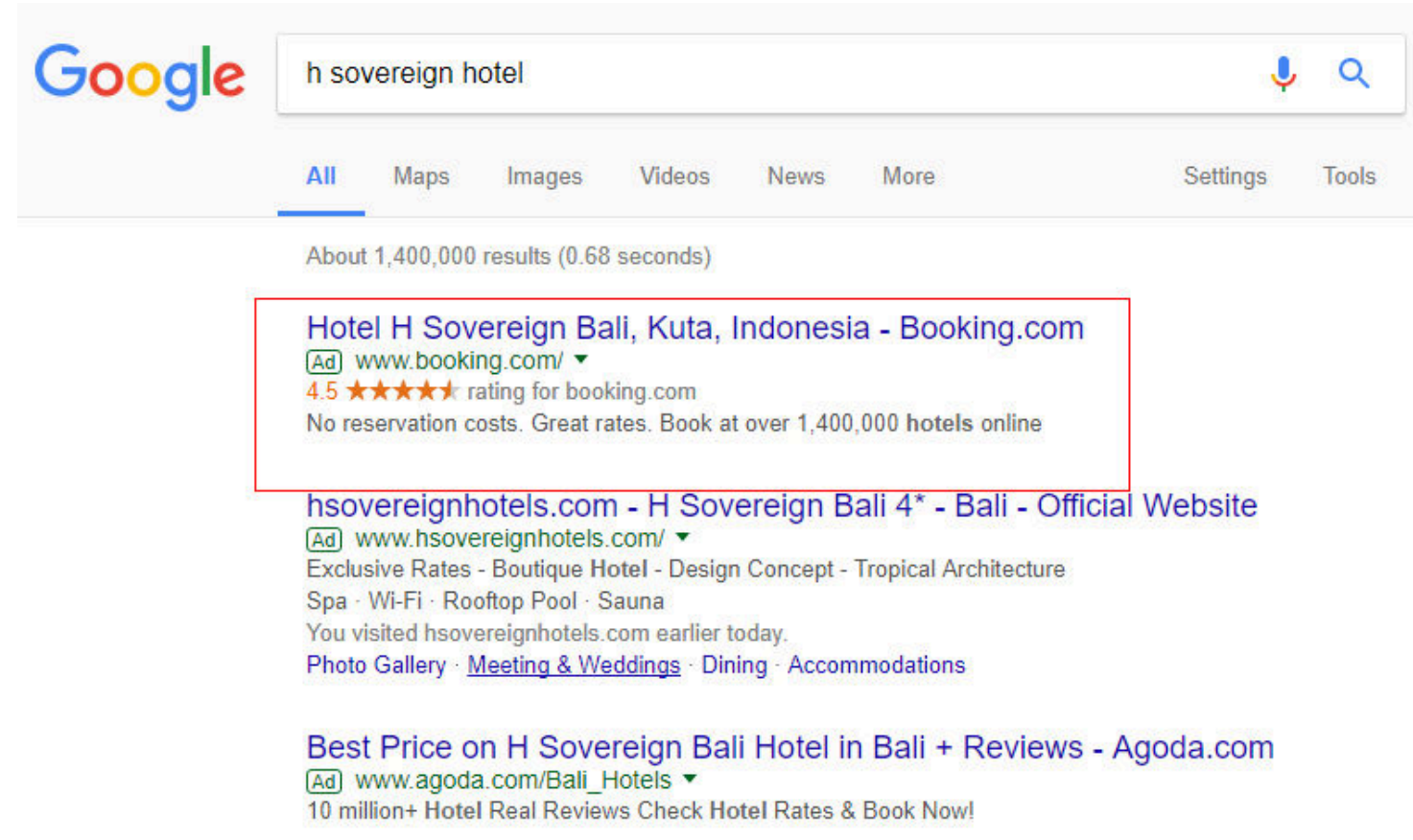

Figure 4.2

The impression of online reservation in H Sovereign Hotel

In Google Inc through site booking.com (photo: Kiki Sanjaya, 2017)

The result of interviews reveals information and also ascertains the fact that the existence of online reservation gives the opportunity to promote hotels which adopted by $\mathrm{H}$ Sovereign today. Theoretically, this action is relevant with Shimp (2000)'s idea that doing online reservation as much as they can would gain much profit in financial and marketing.

Second, one of factors that caused reservation in last-minute commonly happens, it is easy to access reservation process through online reservation. Andi Astika also revealed that the last minute reservation affected by vast promotions offer (especially at low season). The result of an interview with a customer of $\mathrm{H}$ Sovereign Hotel, Ting Xuan Leng could strengthen this assumption.

"I booked a room in last-minute because I don't really have an exact plan for my vacation. Other than that, I could get lots of promotion offered in lastminute by the Hotel and it's really easy to do. So I would not spend lots of money as I am a backpacker..." (interview, September 2, 2017)

The information taken from Ting XuanLeng defines that one of the consumer's reason choosing last-minute reservationis the vast promotions offered by hotel, and also it is easy to do transaction in online (Adi \& Widiyanto, 2013: 18).

\section{Threats}

Next point that will be explained in last discussion is the threats faced in applying online reservation in $\mathrm{H}$ Sovereign Hotel. After interviewed Andi Astika on 3 June, 2017, there are three kinds of threats that possibly faced by H Sovereign Hotel. First, cancellation of room reservation. The cancellation of reservation will inflict a financial loss because based on Astika's explanation, there is a possibility 
that the reserved room can be given to others who are more serious. Second, there is no show. Though no show case is seldom happened in H Sovereign Hotel, but the hotel certainly will suffer some loss if the guests book a room in long days in less deposit. No doubt that only that deposit will be the profit for company. Third, fake booking may decrease the ranking of H Sovereign Hotel. For your information, the hotel ranking will increase when the history reservation of people came into that hotel is rising.

By considering on Astika's information and analyzing it deeply, it can be inferred that despite of online reservation assistance toward hotel's reservation system, there are some threats apparently inflicts a financial loss, then it will be ended in financial loss of the company. The phenomenon occurs in H Sovereign Hotel is relevant with the threats faced from the existence of online service as seen in Turban et al. (2004) theory. In addition, there is also scam risks besides the euphoria of e-commerce in online reservation that having modern jargon, efficient, effective, cheap, and easy to use.

\section{CONCLUSION}

In a state of euphoria of using e-commerce that has implemented in hotel sector, especially in online reservation, by taking H Sovereign Hotel as the object of research, it is found the advantages, disadvantages, opportunities, and threats. The strength of online reservation is it is easy to employ than the conventional reservation, and apparently it extremely contributes the increase of room occupancy in H Sovereign Hotel.

On contrary, its disadvantages depends on internet connection and the operators of hotel are frequently get difficulties to handle the room reservations entered. Although the opportunity of online reservation as media promotion is widely opened and gives good impression to hotel, but H Sovereign Hotel is keep struggling with the threats of scams in online reservation, such as cancellation, no show, and fake reservation that is apparently different with the opportunity given.

Those result above also answered the urgencies of the research. Stated that $\mathrm{H}$ Sovereign doin a great job by adopting the online reservation that become a new way of reservation now days. In fact they struggle with all the disadvantages, and getting benefit from the online reservation system, in the future their system will grow mature. Grow mature mean that along with the mature of technology, internet, policies, and society behaviour. This argumentation proved by fact that the online reservation so far has surpassed the offline reservation in that hotel.

\section{REFERENCES}

Adi, R. N., \& Widiyanto, I. (2013). Analisis Faktor-Faktor yang Mempengaruhi Keputusan Pembelian dengan Sistem Pre Order secara Online (Studi Kasus pada Online Shop Chopper Jersey). Fakultas Ekonomika dan Bisnis.

Bagyono. (2008). Teori dan Praktik Hotel Front Office. Alfabeta.

Bohang, F. K. (2018). Berapa Jumlah Pengguna Internet Indonesia? Artikel ini telah tayang di Kompas.com dengan judul "Berapa Jumlah Pengguna Internet Indonesia?", https://tekno.kompas.com/read/2018/02/22/16453177/berapa-jumlahpengguna-internet-indonesia. Penulis : Fatimah Kar (R. Wahyudi (ed.)). https://tekno.kompas.com/read/2018/02/22/16453177/berapa-jumlah- 
pengguna-internet-indonesia

Shimp, T. A. (2000). Periklanan Promosi. Erlangga.

Sihandrini. (2004). Pengaruh Penggunaan Situs Web Sebagai Alat Pemasaran Secara Online Oleh Hotel Berbintang di Bali. Universitas Udayana.

Sugiarto, E. (2002). Hotel Front Office Administration. Gramedia.

Tjiptono, F. (2002). Strategi Pemasaran (1st ed.). Andi Offset.

Turban, E., King, D., Lee, J., \& Viehland, D. (2004). Electronic commerce: A managerial perspective. Prentice Hall.

Vermaat. (2007). Discovering Computers: Menjelajah Komputer Fundamental (3rd ed.). Salemba Infotek. 